\title{
The Impact of CSR Dimensions on Customer Participation Behaviour in Banking Industry of Pakistan
}

\author{
Muhammad Mubushar, Norizan Bt Jaafar, \\ Rossazana Bt Ab Rahim, Hasnain Manzoor and \\ Muhammad Imtiaz Haider
}

\begin{abstract}
This papers examines the impact of Customer dimension of CSR, local community dimension of CSR, employee dimension of CSR, supplier dimension of CSR on customer participation behaviour. Data was collected from 453 banking customers of Pakistan. Smart PlS was used to test the measurement model and structural equation modelling technique was run to test the hypotheses. The study found that all corporate social responsibility initiatives have positive impact on customer participation behaviour. The customer dimension of CSR have more influence to for active participation of customers followed by the local community dimension of CSR, employee dimension of CSR and supplier dimension of CSR. This study covered all primary stakeholders under the head of stakeholders' theory and highlighted the importance of supplier-oriented corporate social responsibility for customer participation behaviour due to end-users. This study also sheds the light that customers have been changing their role from passive participation to active participation.
\end{abstract}

Keywords--- Impact of CSR Dimensions, Banking Industry of Pakistan.

\section{INTRODUCTION}

In the present age of developments, corporate social responsibility has been becoming more and more important function for the corporations (Amoroso, Roman \& Morco, 2016; Ermayanti, Grahita \& Boge, 2019). Research has shown that corporate social responsibility affects directly or indirectly to the perception of customer so that, why they are more aware about the different social and environmental issues (Huber et al., 2011). A considerable amount of research attention has devoted to explore the relationship between CSR and organizational value (Wong \& Gao, 2014; Joo, Moon \& Choi, 2016) but a few studies shaded the light on the relationship between CSR and decision making of consumers (Moisescu, 2015; Saleh, Ebeid \& Abdelhameed, 2015). For instance, they examined the relationship of CSR initiatives and customer preferences such as loyalty (Liu et al., 2014; Chung et al., 2015), Studies also checked the customers' attitude and behaviour that is shaped by the corporate social responsibility (Zaharia \& Zaharia, 2013). These studies lacked to incorporate stakeholder-centric CSR dimensions and checked its impact on other outcomes of customers' behaviour.

Muhammad Mubushar, Ph.D. Scholar, Faculty of Economics and Business, Universiti Malaysia Sarawak (UNIMAS), Kota, Samaharan Malaysia.E-mail: Mubushar.raja@gmail.com

Norizan Bt Jaafar, Senior Lecturer, Faculty of Economics and Business, Universiti Malaysia Sarawak (UNIMAS), Kota, Samaharan Malaysia.E-mail: jnorizan@unimas.my

Rossazana Bt Ab Rahim, Associate Professor, Faculty of Economics and Business, Universiti Malaysia Sarawak (UNIMAS), Kota, Samaharan Malaysia. E-mail: arrossazana@unimas.my

Hasnain Manzoor, PhD Scholar, Comsat University Islamabad Wah.E-mail: Hasnain4343@gmail.com

Muhammad Imtiaz Haider, PhD Scholar, Capital University of Science and Technology Islamabad. E-mail: mimtiazhaider@gmail.com 